\title{
Deictic Close Reading
}

\author{
ARNE MERILAI
}

\begin{abstract}
Inspired by practical didactics, this article suggests using pragmapoetic deictic analysis as a method to enrich close reading of poetry. When applying the pragmalinguistic theory of deixis and the analytic philosophical theory of indexicals to poetic texts, it soon becomes apparent that, in addition to traditional spatial, temporal, and personal deixis, it is also necessary to speak about emotional, or modal, deixis. The latter functions on a scale of positive and negative connotations, or, of subjective distance, which is the mental counterpart to spatial relations. In addition, poetry amplifies the intuitive deictic and egocentric quality of ostensive words of natural kind. On a formal level, however, we notice a congenital enhancement of discourse (or text) deixis, which manifests itself via self-reference using linguistic equivalence. This theory is exemplified by a deictic analysis of a short poem by Ene Mihkelson, which reveals the poem's orientational reference system as a deictic network onto which an imaginary plot of the poem is projected. It should be noted that a deictic plot is wider than a lyrical/poetic plot, the latter being a concretization of the deictic potential created in the author's or reader's consciousness through the course of reading. Accordingly, we pass through three levels of analysis: (1) deictic network as the orientational frame of reference in the analyzed text, (2) deictic plot as the possible spatial and temporal dynamics of poetic thought within that frame of reference, and (3) lyrical plot as the concretization of a potential deictic plot in the conscious mind of the author or reader.
\end{abstract}

Keywords: deixis; indexicality; emotional/modal deixis; deictic network; deictic plot; pragmapoetics; close reading; poetry

Philology is the science of texts, combining linguistics, poetics, and history. The further linguistics moves away from texts, or literary studies from language, the less remains of philology. Modern-day literary scholars should be considered more as cultural researchers, not philologists, just as linguists themselves are more language technologists. Simply using terms such as

1 The initial version of this article, "Deiktiline lähilugemine," was published in Estonian in Keel ja Kirjandus 2016, 8-9, 669-680.

DOI: https://doi.org/10.12697/IL.2020.25.1.4 
philologist or philology does not yet guarantee content corresponding to the name. The most genuine Estonian philologists are our native language and literature teachers - our salt of the earth. Poetics-centric close reading of a text is one of the core activities of literary studies and assumes linguistic competence. In close reading, one observes prosodic, lexical, syntactic, or semantic levels to achieve explanatory in-depth interpretations. Pragmatic questions such as the analysis of poetic speech acts or implicatures have unfortunately found less application in close reading, probably because the study of speech acts emerged only after the development of close reading. However, in poetry analysis seminars, I also often experience that casually involving deictic observation offers something extra to explicit close reading, which is why I believe this methodical tool is worth introduction.

\section{Pragmapoetic Background}

Poetics derived from the study of speech acts is called pragmapoetics (see Merilai 2003,2001), to which pragmalinguistics offers a parallel. I consider the theory of poetic language to be the basic discipline of philological literary science, combining the philosophy of language and mind, linguistics, and literary science. Pragmapoetics pays special attention to figurative thinking and language use, specifically literary and rhetorical speech acts, semantic and syntactic implicatures - tropes as figures of thoughts and schemes as figures of words ${ }^{2}-$, the nature of fictional speech, the deixis of the content of text and form, or, in other words, the associated orientation of external as well as textual contexts. Deixis is not really an unknown term or concept in Estonian philology; it has been introduced from both poetic and (socio-)linguistic viewpoints (see Merilai 1995, 2003: 17-37, 2005; Pajusalu 1999; Monticelli et al. 2005; Mueller 2015a: 57-66, 2015b; Larjavaara 2007). In the wider world, cognitive linguistics and poetics have taken more of an interdisciplinary interest in applying deixis, using cognitive science data in an attempt to explain how language or literature functions (see Brisard 2002; Stockwell 2008). A cognitivist approach to literature puts poetic and rhetorical hermeneutics again at the center of research for addressing (the reader's) phenomenological perception and effects - the cognitive aspects of a text's physical and mental influence (see Tsur 1992, 2008; Duchan et al. 1995; Bex et al. 2000; Semino,

2 I have come to the conclusion that schemes are syntactic implicatures applying Grice's maxims of manner while tropes apply semantic maxims of relation and quality. 
MERILAI

Culpeper 2002; Gavins, Steen 2003; Stockwell 2002, 2009; Veivo et al. 2005; Brône, Vandaele 2009; Dancygier 2014).

Lately nothing fundamentally new has been added to earlier research on the nature of deixis, such as what was introduced by psycholinguist Karl Bühler (cf. 1990 [1934]) and further developed by a number of experts in semantics and pragmatics (see Jakobson 1971 [1957]; Lyons 1977; Levinson 1983; Rauh 1983; Frawley 1992; Fillmore 1997); instead there is a tendency to get mired in details rather than to generalize. Analytical philosophy, which preceded linguistics, is incapable of getting to the root of the problem, although Charles Peirce's indexes (1931) and Bertrand Russel's egocentric particulars did help to establish an analytical reference and a theory of demonstratives (see, for example, Reichenbach 1966 [1947]; Donnellan 1990[1966]; Kripke 1990 [1977]; Kaplan 1979; Searle 1983; Evans 1985; Recanati 1993). This form of thought is also hindered by the fact that a token's self-referentiality (or set theory paradox) has so far not been mathematically well formalized.

But we can always roll up our sleeves and become makers of theory. Deictic analysis of a text proves to be an effective and fascinating tool for close reading. Its explanatory power has not yet been fully understood by textual scholars nor have opportunities for continued development and interpretive creativity. Hopeful aspirations arose some time ago (e.g., Fowler 1986; Green 1992, 1995; Mey 1999), but, aside from the attempted interdisciplinary leap into the field of cognitivism, no great steps have been taken.

So, what is deixis? A summary of earlier-available, easy-to-find concepts does not seem to make much sense here, so I will give a brief overview of the wisdom brought out in my own experience of didactic pragmapoetics.

1. Language deixis is a discursive orientation network. Each speech act is an act of establishing its own context and orienting itself within it, an act of coding and decoding the perspectives of the utterance. Therefore, a speech act is also a contextually coherent orientation act. Deixis not only describes its own context, but also creates and demonstrates the context in which the expression functions. Deictic constructivism is made clear in poetry analysis. Deixis first declares its time-space and what can be found there. In poetry also: the content of the poem is placed in the context, which was made with the poem's own words. Constructing seems to be the primary function, while describing is the second. Deixis is an apparatus for creation and recreation: in close reading, this occurs in slow-motion. 
2. Deictics (not only deictic vocabulary, but any deictic expression) reveal the natural self-referentiality of language since characteristics of contextually bound indexical expressions, or, in other words, specific time-space references are determined by whether one knows the rules of use of these expressions. If we do not know how to use an expression, then the reference will not occur. So, the expression must be understood for the reference to exist. For example, the reference for the personal deictic you changes from context to context or from utterance to utterance; however, these changing references are identified by an unchanging understanding: if the speaker says you, then, in English, the word you refers to the speaker's partner in the conversation. Whenever the temporal deictic yesterday is used, then the previous day is referenced in relation to the time at which the utterance is made. Of course, all language receives feedback this way, but in deixis, this must be made clearer. Although deictic auto-reference is implicit or relatively unnoticeable to the speaker, it becomes much more explicit in a poetic environment: a linguistic expression is emphasized alongside its content or even brought to the foreground at the expense of content, becoming an independent goal or valued object. This is based on Gottlob Frege's principle: one must first grasp the meaning of an utterance in order to find its reference. Thus, the primary reference points to the means of an expression itself and only then to the expression as content. In a poetic context, the means of an expression becomes more opaque, forcing recipients to deal pre-referentially with the composition of the expression itself and the possible ideas that lie hidden there. As Shklovsky said: slowing down one's perception while tackling defamiliarization of meaning is the basis for aesthetic experience.

3. Deictic theory emphasizes the egocentricity of the speaker's viewpoint (origo). However, this should be taken more generally, assuming not inevitable subject-centeredness, but rather utterance-centeredness: the utterance itself is the zero point of orientation, which also places the subject of that utterance at the starting point. A parrot, a speech machine and an artificial letter, or a non-existent fictional author may also convey something intelligible or create this illusion, but we do not consider these to be subjects with consciousness.

4. Deixis works by contrasting proximity and distance and is thus initially spatial. Orienting is primarily a spatial activity. Time is also perceived in terms of spatial relationships: as distance, as a journey, as movement from one point to another, as flowing backwards and forwards. The utterance is the starting point for the coordinates around which the immediate area of 
MERILAI

the utterance is centered; beyond this is the distant sphere, which in turn is surrounded by an even more distant background: $I$ / we - you (sing.) / you (plur.) - he/she/they; here - there; now - before/after - earlier/later - ever/ sometime. Expressing the placement and movement in time and space is all deictic: to come/to go; in - out - off; under - over - in front - behind - beside away; a long time ago - before - now - after - sometime. Besides personal, spatial, and temporal deixis, there is also social deixis, e.g., in Estonian, the capitalized polite form Teie (You) denotes respect or a higher position.

5. The closer one gets to poetry, the more important it becomes to carry the actual or fantasized real deixis over to the emotional and modal sphere. The semanticists John Lyons (1977), who first used the term modal or empathic deixis, and Charles Fillmore (1971a, 1971b) and Robin Lakoff (1974), who preferred the term emotional deixis, drew attention to subjective attitudinal deixis. We want to bring the good close to our souls but push away the bad. The typical conflict between mind and body or the chiasmus of deictic vectors: we feel bad and it hurts, and we do not like it one bit. Like Jüri Üdi said in his haiku: "Japan is far / Estonia is farther still." The ESSR was close to the body but repulsive to the mind, while the late Estonian republic warmed the heart yet was beyond seven lands and seas: so close, but so far. Irony, possibility, imagination, fiction - this all plays on the deictic distinction of the actual and the possible, the desirable and undesirable, the present and imagined but nonexistent worlds. Disgusting: revolting and rejective; lovely: cuddly and heart-warming.

Fantasy deixis, or imaginative context creation, is the basis of literature. "Lumehelbeke / tasa, tasa” ('A little snowflake / softly, softly') by Juhan Liiv immediately establishes a context, an imaginary image, for its content, which opens up a vertical dimension (spatial relationship) from earth to sky, achieves a diminutive approach (spiritual relationship) of a fragile and tiny object with the use of the ke-particle, and instills a soothing sense of slow motion (spiritual and temporal relationship). Thus, emotional deixis, emotional modality begins to play a special role in poetry: each expression brings diverse perceptual aspects and spiritual attitudes. Following a pragmapoetic understanding of metaphor (see Merilai 2003: 141-150; Merilai et al. 2007: 41-46), words can be interpreted as semantic sets, which are embedded with many items, basic or co-meanings, as elements. For example, the term sun as a semantic set represents the following meanings in our consciousness: above, sky, hot, far, shine, dazzle, scorch, radiate, revive, awaken, rise, set, sometimes behind clouds, round, like a rolling wheel, the most important, light source, wave emission, the opposite of the moon and 
night and darkness, moving in an arc, over the zenith, from the northeast to northwest, across the south, more active in summer, scientifically gaseous, heliocentric, and more. These elements of meaning are associated with positive, negative, and neutral emotional connotations in our consciousness. The preponderance of the word's meaning cloud (or its applied subset) toward a more positive or negative side determines its emotional charge, which, when put together with other words, is summarized as a positive or negative impression of the text as a whole. It is still a wonder how poems can convey a feeling of subtlety that sometimes seems inexplicably elusive and brilliant. But all nuances, half and quarter tones, are given in an emotionaldeictic interplay of word choice, which is a linguistically objective endowment and thus also, in principle, subject to analysis.

6. There is an abundance of deictic morphology and vocabulary for expressing spatial, temporal, personal, and attitudinal relationships: pronouns, nouns, verbs, adverbs, prefixes, suffixes, cases, conjugations, conventional or conversational implicatures. Indexical expressions are not all that play a role in orientation. Symbolic words also function as deictics, especially in natural, ostensible surroundings. Such a worthy addition, however, does not come from linguistics, but again from analytical philosophy. Following in the footsteps of Saul Kripke's possible worlds and rigid designator theory, Hilary Putnam understood that words of a natural type (such as water, etc., and words like $I$ ) are by nature (albeit imperceptibly) indexical (Putnam 1973). Such an important conclusion leads us directly to an important generalization: all essential features of spatial deixis are applicable to socalled natural words. Indeed, if anything, this type of vocabulary tends to be deictically active: tree - from bottom to top, expanding above, on the spot; water - below, standing, falling, or flowing ("around here," says Putnam); rain - from top to bottom, straight or at an angle, encompassing; sun, moon, stars, clouds - above, in slow circulation; rock - below, under, a coordinate; soil - low, expansive, ground and underground (see also Merilai 2003: 18-20). Likewise, verbs, when defining temporal relations, represent both movement and its opposite states, i.e., physical or mental places as well as changes of place.

7. The time-space of text creation, reception, and content (with fixed or shifting views) are all different levels of deixis. Even negation is interpreted as a type of deixis, as modality: creating a negative contrast or an opposing place. Similarly, deontic and epistemic modality can be understood deictically, in the distance and contrast of actual and possible places: I want 
MERILAI

it, but it is not - it must be achieved; don't know - would like to know (see Frawley 1992: 384-435).

8. Discourse or textual deixis represents a completely different playground: the formal self-orientation of an expression. This is the backward and forward referencing of reciprocal, formal units of text, the formal distances within the fabric of the textual space, character space in the literal sense of the word. Any metrically equivalent or contrasting syllable, initial rhyme, end rhyme, or any repetition points to itself as well as to its own foregrounded or backgrounded analogues. Diverse form parallelism elevates these units to the foreground. An expression in formally integrated speech is thus inevitably also actively discourse deictic: the various formal positions of a text are intertwined with a dense network of diverse implicit and explicit self-references. This integration scheme of poetic language is well illustrated in the Poeetika ('Poetics') high school textbook with the first verse of Hando Runnel's poem "Üks veski seisab vete pääl” ('Upon the Waters Stands a Mill'). The dense "spider web" is also an illustration of discourse deixis (Merilai et al. 2007: 36). Such a conception of deixis, which broadens the meaning of the term, may seem unfamiliar at first, but the Ockham principle supports this: it makes no sense to coin a new term, wherein regular deixis would comprise only a small sub-part.

9. The various types of deixis mix well: time, space, referentiality, emotionality, discursiveness. The diversity of deictic aspects often manifests in one and the same expression. But it all comes down to distinguishing plus, minus, and plus/minus, the contrast of proximity, distance, and neutrality, the game of differences. Therefore, when approached deictically, the binary contrast principle becomes the basis of literature.

\section{The Deictic Network and Plot}

For our analysis, we will borrow Ene Mihkelson's free verse poem "Valge kala ujub läbi metsa” ('A White Fish Swimming through the Forest'). Since deictic primary data tend to expand, then studying a haiku-like, laconic text might save printing space. In this sense, it may be better to adopt a more generalized stance, although some primary assumptions may be overshadowed because of it. When interpreting, I always start with the so-called literal method, initially taking a line of poetry at its most literal level, free of metaphor, as if the act is real deixis. The advantage is that the literal level is written in black and white, while figurative implications are speculative: figurative content is supposedly 
represented in conceptual discourse but is missing from the actual text itself. Only after unlocking the autologous potential do I move to the next level with the layers of transferred meaning. In this way, we do not jump too fast to a non-literal conclusion and instead remain longer in the zone of the first literal reference. Metaphor is a function of literal meaning: we have a habit of quickly finding and satisfying it with its non-literal meaning, while moving away from our initial literal black-and-white assumptions. However, all semantic levels, both explicit and implicit, have some part in the layers of meaning in poetry.

Valge kala ujub läbi metsa

pilv hääletus ookeanis

Ma olen selle kala südames

(Mihkelson 1978: 32)

[In translation:

A white fish swimming through the forest

cloud in a soundless ocean

I am in the heart of this fish]

As we progress with analysis, the literal references and co-references in the text, primary and auxiliary, gradually begin to unfold. A spatial-deictic network forms, inside of which is a forward-moving, emotionally charged spatial-deitic plot. Although we have not yet encountered such notions - deictic network and deictic plot - their appearance here seems to be reason enough to coin these concepts ad hoc. Deictic network and plot brought out through close reading are not equivalent to the meaning of the poem (despite its principle of openness), as both are clearly redundant with respect to the latter; not all listed details and nuances are essential to forming dominants of meaning, so some of the possible information contained in the poem will remain more passively in the background of our perception. And the deictic plot certainly does not identify with the lyrical plot since much of its potentiality may not belong to the author's application nor to the reader's horizon of reception. The deictic network and plot represent a semantic background and support structure; they carry and support possible messages in the text without being an objective themselves. Part of this deictic structure is formed consciously, part intuitively or pre-consciously, but much of it comes naturally with the language itself, a rather unrealized potential that does not actively influence the meaning of the text. 
MERILAI

1. The meaning of the poem's first symbolic word white is implicitly deictic: this manifests itself in relation to darkness, which creates a positive and negative contrast. The dual opposition forms a contrasting juxtaposition that activates a mental, collateral spatial relation. Contrast deixis, deixis of opposing areas, has not yet been mentioned in deictic theory, but it seems important for analyzing poetry, as well as fiction or irony. Also important is the association of purity, which instills a positive feeling.

2. The symbolic word fish represents a smaller point in the surrounding environment. This nature deictic immediately creates the context for a body of water, at the very least an aquarium: since the fish is swimming, then it is not dry. A fish swims in its own element, naturally below the observer who perceives it from land. The fish moves by swimming; this is a vectorial and predominantly horizontal activity: head in front, fins and tail flickering behind, pushing it forward or keeping it in place.

As emotional deixis, the meaning of the fish seems to be neutral at first, containing possibilities for negating itself. Something can be cold and mute like a fish, with a short memory and rotting first in the head, which tends to be negative; but fish as food tends towards positive. Culturally, a fish may refer to Jesus Christ, which would be considered by many to be good. However, a single, determined fish - smoothly, respectfully, understandably evokes sympathy in connection with its sense of independence and purpose for its unexplained goal.

Unless we are talking about the stomachs of sharks or ray, fish tend to be more silvery than white. In the wild, albinos stand out, causing alienation. However, this poem does not seem to suggest negativity, so in being white, the fish is somehow elevated from its element: a cultural fish belonging already to the next level of interpretation, to the metaphorical space. In the most general sense, a white fish could represent purity, or, more specifically, pure poetry, culture, spirituality, or a mix of these. The lyrical self is eager to settle at the heart of this community, as will be made clear. Hence Hermann Melville's Moby Dick, the white whale, as an Old-Testament-like punishing spirit is not at first glance an active parallel; the need for symbolism is what binds these motifs.

3. The nature deictic swimming works as both spatial and temporal deixis, describing a flickering-smooth and forward-moving activity at a given point in time, which brings the present view and future perspective into play.

4. The deictic through defines the penetration of the environment, orienting from one spatial point to another. 
5. The phrase through the forest adds a vertical dimension to the horizontal background: the forest is naturally upright. At the same time, the first dramatic shift from the earlier regular context occurs as the body of water suddenly gives way to the forest. The fish is no longer in its element, which creates a contrasting lake-forest connection. The entire environment is thus raised from below to above, from the lake to aboveground. A powerful movement that equally surprises and satisfies. A forest is an inclusive and more or less delimited area like a lake (not like a river or sea), comprised of empty or filled pillars: trunks and the airspace between them. The forest has a prohibitive function; while moving through it, one must negotiate the resistance of material and would therefore benefit from a sense of space.

6. From a textual deictic perspective, the small letter $c$ at the start of the second line suggests that both the first and the second verses belong to one period; this instills a sense of repetition which in turn indicates a reversal of attention. However, as literal or figurative periphrasis, the nature deictic cloud raises the wilding lake even higher, straight into the sky, which is already a third degree of gradation. Despite its hazy boundaries, the cloud delineates itself as a unit comparable to the size of the lake and forest, a phenomenon somewhat similar to the blurred edges of a forest's brushwood. The wilding cloud obstructs from the inside and is opaque at a distance, yet permeable. Ambiguity is assumed in poetry, so let's be clear: either the cloud is a forest lake with the fish inside - which seems to be a stronger association or the white fish is the white cloud whose environment expands into the ocean. The white color of the fish and the aqueous composition of the body of water are easily associated with the white cloud.

7. The vast ocean, a new context for the fish, is somehow soundless. Why? Does the world's sea not rumble or is it mute like the fish? Or is the listener himself deaf? From an emotional-deixis point of view, this soundlessness may also have a pleasing effect, representing noise-free purity secondarily to the meaning of the color white. As the poem was published in 1978, the meaning of soundless could also be interpreted as a between-the-lines allusion to censorship or a speech impediment of subalterns under the power of the dominant discourse. This possible signal does not seem to be very active here, but at the same time, comparative-historical background radiation should not be completely ignored. The literary critic must constantly decide to what extent meanings can be attributed to the text to prevent projections from becoming overly interpretive: Jaan Kaplinski's "Vercingetorix" was not only an expected allegory of our fight for freedom. 
MERILAI

However, it is not a sin to refer to other connotations and allusions by using assumptions as weaker statements instead of certain assertions.

8. The poem culminates by bringing the focus back from the borders of infinity to the minimal point of collaboration, i.e., to the perspective of the fish, forcing itself into a tiny atom opposite the ocean. We have the fish as the coordinate, and in the fish is an even smaller point, the fish's heart. But inside this point, or heart, is an even smaller dot: the lyrical self. The external (extradiegetic) spectator of the poem now doubles as the internal (intradiegetic) self. We are used to treating self-consciousness as an endlessly expanding internal space. Thus, the inner world may be taken as inversely proportional counterpoint to the external ocean: it is a mirror image of infinity in its introspective dimension. The fish is put under a magnifying glass, which then focuses on its heart, which in turn frames the conscious being residing there. That cordial inhabitant, in turn, is itself the frame for the soul's inward-expanding ocean: a shrinking microscope that swells again into a telescope.

9. The compressed spatial anti-climax forms an inverse gradation, creating a spatial hourglass with the fish as the neck, the fish's heart as the point of transition, and the lyrical self as the grain of sand passing through the portal between the two universes. The latter is comprised of two expanding oceans: the symmetrical cones of the outer and inner worlds, which we may call ocean and ocean $_{2}$. Or matter and anti-matter, as they used to say in earlier astronomy.

Therefore, one may map the poem's deictic plot accordingly (see Figure 1):

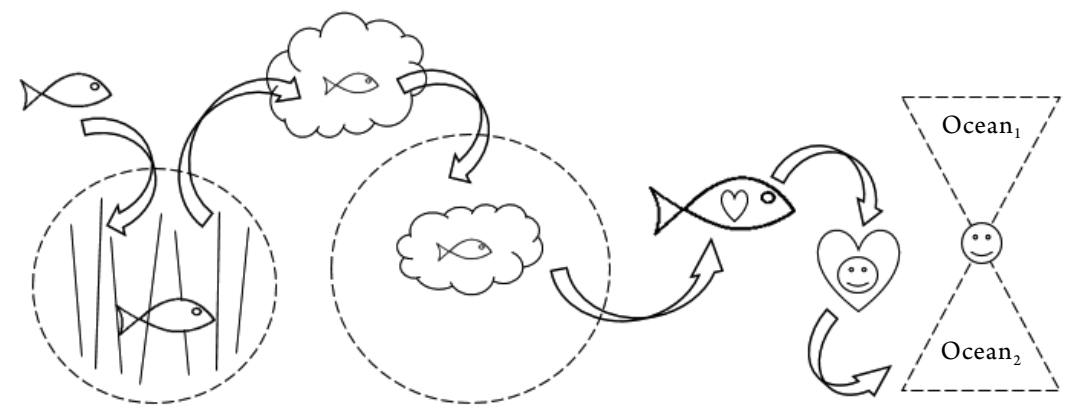

Figure 1. Deictic plot 
Deictic Close Reading

\title{
Conclusion
}

Since the white fish seems to represent purity and the concept of freedom, and the lyrical self feels like a fish in the water at the core of all this positivity, then the figurative language implies that the subject in question perceives herself to be purer than pure (because otherwise the fish would be poisoned and starting to rot - but this time from the heart). The lyrical self is both horizontally and vertically capable, free in the internal and external spheres despite the situation's voiceless and temporary obstacles. If we approach the meaning of the text in this way, then it is a luminous proclamation: it acts both as a moral statement of self-determination (declarative) as well as an expression of happiness and well-being (expressive).

Against the background of such a meaning dominant, the deictic network and plot contributed significantly towards achieving an outcome, enriching communication with the text with an extra game. Deictic study is an effective and enjoyable close-reading tool that offers new, eye-opening linguistic and cognitive aspects to initial impressions in poetry analysis, likely many of which the author herself did not even consider. It is an old adage that a poem's figurative entirety never completely matches what the author envisioned, especially given readers' various reading styles and Heidegger's concept that language itself has a speech, which precedes man. However, there is always a need to strive for a greater commonality, both by authors and readers.

So: a deictic study of Ene Mihkelson's short poem reveals the text's orientation framework as a deictic network. The possible deictic plot is then projected onto the deictic network as temporal-spatial-subjective movement of the imagination. The deictic plot, constructed through close analysis of the text, is a broader frame phenomenon for the lyrical/poetic plot, a deictic potential that concretizes in the mind of the author or reader. Therefore, three levels of analysis emerge: 1.) the deictic network as the general orientation framework, 2.) the deictic plot as a possible chronotopical dynamic of the poetic thought within the context of the orientation framework, and 3.) the lyrical plot as the concretization of the potential deictic plot in the mind of the author or reader.

\author{
Arne Merilai \\ arne.merilai@ut.ee \\ Tartu Ülikool \\ Ülikooli 16-110 \\ 51014 Tartu \\ EESTI / ESTONIA
}


MERILAI

\section{References}

Bex, T., Burke, M., Stockwell, P. 2000. Contextualised Stylistics. Amsterdam: Rodopi.

Brisard, F., ed. 2002. Grounding: The Epistemic Footing of Deixis and Reference. Cognitive Linguistic research, 21. Berlin; New York: Mouton de Gruyter.

Brône, G., Vandaele, J., eds. 2009. Cognitive Poetics: Goals, Gains and Gaps. Applications of Cognitive Linguistics, 10. Berlin; New York: Mouton de Gruyter.

Bühler, K. 1990. Theory of Language: The Representational Function of Language. Foundations of Semiotics, 25. Amsterdam; Philadelphia: John Benjamins.

Dancygier, B. 2014. Intensity and Texture in Imagery. - P. Stockwell, S. Whiteley, eds., The Cambridge Handbook of Stylistics. Cambridge: Cambridge University Press, 212227.

Donnellan, K. 1990 [1966]. Reference and Definite Descriptions. -The Philosophy of Language. $2^{\text {nd }}$ ed. Ed. A. P. Martinich. Oxford; New York: Oxford University Press, 235-247.

Duchan, J. F., Bruder, G. A., Hewitt, L. E., eds. 1995. Deixis in Narrative: A Cognitive Science Perspective. Hillsdale; New Jersey etc.: Lawrence Erlbaum Associates, Inc.

Evans, G. 1985. Understanding Demonstratives. - G. Evans. Collected Papers. Oxford: Clarendon Press, 291-321.

Fillmore, C. J. 1971a. Toward a Theory of Deixis. - University of Hawaii Working Papers in Linguistics, 3/4, 219-242.

Fillmore, C. J. 1971b. Santa Cruz Lectures on Deixis. Reproduced by the Indiana University Linguistic Club. Bloomington, Indiana.

Fillmore, C. J. 1997. Lectures on Deixis. CSLI Lecture Notes, 65. Stanford, California: CSLI Publications.

Fowler, R. 1986. Linguistic Criticism. Oxford; New York: Oxford University Press.

Frawley, W. 1992. Linguistic Semantics. Hillsdale; New Jersey etc.: Lawrence Erlbaum Associates, Publishers.

Gavins, J., Steen, G. 2003. Cognitive Poetics in Practice. London: Routledge.

Green, K. 1992. Deixis and the Poetic Persona. - Language and Literature, 1(2), 121-134; also R. Carter, P. Stockwell, eds., The Language and Literature Reader. London; New York: Routledge, 2008, 127-136.

Green, K., ed. 1995. New Essays in Deixis: Discourse, Narrative, Literature. Costerus New Series, 103. Amsterdam; Atlanta: Rodopi.

Jakobson, R. 1971 [1957]. Shifters, Verbal Categories, and the Russian Verb. - R. Jakobson. Selected Writings II: Word and Language. Hague etc.: Mouton, 130-147.

Kaplan, D. 1979. The Logic of Demonstratives. - P. H. French, T. Uehling, Jr., H. Wettstein, eds., Contemporary Perspectives in the Philosophy of Language. Minneapolis: University of Minnesota Press.

Kripke, S. 1990 [1977]. Speaker's Reference and Semantic Reference. - A. P. Martinich, ed., The Philosophy of Language. $2^{\text {nd }}$ ed. New York; Oxford: Oxford University Press, 248-267.

Lakoff, R. 1974. Remarks on This and That. - Proceedings of the Tenth Regional Meeting of the Chicago Linguistic Society, 10, 345-356. 
Deictic Close Reading

Larjavaara, M. 2007. Pragmasemantiikka. Helsinki: Suomalaisen Kirjallisuuden Seura. Levinson, S. C. 1983. Pragmatics. Cambridge: Cambridge University Press.

Lyons, J. 1977. Semantics. Vol. 2. Cambridge: Cambridge University Press

Merilai, A. 1995. Artur Alliksaare luule pragmaatika I: Deiksis. - Akadeemia, 10, $2086-$ 2111, 2204-2205.

Merilai, A. 2001. Poetic Speech Acts. A Hypothesis of Two Contexts. - Trames: Journal of the Humanities and Social Sciences, 2, 5(55/50), 157-176.

Merilai, A. 2003. Pragmapoeetika: Kahe konteksti teooria. Studia litteraria Estonica, 6. Tartu: Tartu Ülikooli Kirjastus.

Merilai, A. 2005. Regarding Pragmapoetics: Deixis. - D. Monticelli, R. Pajusalu, A. Treikelder, eds., Regards multidisciplinaires sur la deixis: de l'énoncé à l'énonciation et vice-versa. Multidisciplinary views on deixis: from utterance to uttering and vice versa. Multidistsiplinaarsed vaated deiksisele: lausungist lausumiseni ja vastupidi. Université de Tartu, Centre d'Etudes Francophones Robert Schuman. Studia Romanica Tartuensia, IVb. Tartu: Tartu Ülikooli Kirjastus, 271-285.

Merilai, A., Saro, A., Annus, E. 2007. Poeetika: Gümnaasiumiõpik. Tartu: Tartu Ülikooli Kirjastus.

Mey, J. L. 1999. When Voices Clash: A Study in Literary Pragmatics. Berlin: Mouton de Gruyter.

Mihkelson, E. 1978. Selle talve laused. Tallinn: Eesti Raamat; also E. Mihkelson. Kaalud ei kõnele: Valitud luuletusi 1967-1997. Tallinn: Tuum, 2000.

Monticelli, D., Pajusalu, R., Treikelder, A., eds. 2005. Regards multidisciplinaires sur la deixis: de l'énoncé à l'énonciation et vice-versa. Multidisciplinary views on deixis: from utterance to uttering and vice versa. Multidistsiplinaarsed vaated deiksisele: lausungist lausumiseni ja vastupidi. Université de Tartu, Centre d'Etudes Francophones Robert Schuman. Tartu: Tartu Ülikooli Kirjastus.

Mueller, M. 2015a. The Use of Repetition in Betti Alver's Poetry: A Stylistic Analysis. Master's Thesis. University of Tartu, Faculty of Philosophy, Institute of Estonian and General Linguistics, Department of Estonian as a Foreign Language. Tartu: Tartu University.

Mueller, M. 2015b. Parallelism as Repetition: A Case Study of Betti Alver's Elu on alles uus and Jälle ja jälle. - Methis: Studia Humaniora Estonica, 16, 86-105. https://doi. org/10.7592/methis.v13i16.12454

Pajusalu, R. 1999. Deiktikud eesti keeles. Tartu: Tartu Ülikooli Kirjastus, 1999.

Peirce, C. S. 1931. Collected Papers of Charles Sanders Peirce, Vol I. Cambridge, Massachusetts: Harvard University Press.

Putnam, H. 1973. Meaning and Reference. - The Journal of Philosophy, 70, 699-711. https://doi.org/10.2307/2025079

Rauh, G., ed. 1983. Essays on Deixis. Tübingen Beiträge zur Linguistik, 188. Tübingen: Gunter Narr Verlag.

Recanati, F. 1993. Direct Reference: From Language to Thought. Oxford; Cambridge (USA): Blackwell.

Reichenbach, H. 1966 [1947]. Elements of Symbolic Logic. New York: The Free Press; London: Collier-Macmillan Limited. 
MERILAI

Russell, B. 1940. An Inquiry into Meaning and Truth. London: G. Allen \& Unwin.

Searle, J. R. 1983. Intentionality: An Essay in the Philosophy of Mind. Cambridge: Cambridge University Press.

Semino, E., Culpeper, J., eds. 2002. Cognitive Stylistics: Language and Cognition in Text Analysis. Amsterdam: John Benjamins.

Stockwell, P. 2002. Cognitive Poetics. London; New York: Routledge.

Stockwell, P. 2008. Cognitive Poetics and Literary Theory. - Journal of Literary Theory, 1(1), 135-152. https://doi.org/10.1515/JLT.2007.008

Stockwell, P. 2009. Texture: A Cognitive Aesthetics of Reading. Edinburgh: Edinburgh University Press.

Tsur, R. 1992. Toward a Theory of Cognitive Poetics. Amsterdam: North-Holland.

Tsur, R. 2008. Deixis in Literature: What Isn't Cognitive Poetics? - Pragmatics and Cognition, 16(1), 119-150. https://doi.org/10.1075/pc.16.1.08tsu

Veivo, H., Petterson, B., Polvinen, M, eds. 2005. Cognition and Literary Interpretation in Practice. Helsinki: Helsinki University Press. 